\title{
DO WE OWE OUR INTELLIGENCE TO A PREDATORY PAST?
}

\author{
C. K. BRAIN
}



SEVENTIETH

JAMES ARTHUR LECTURE ON

THE EVOLUTION OF THE HUMAN BRAIN

2000 

SEVENTIETH

JAMES ARTHUR LECTURE ON

THE EVOLUTION OF THE HUMAN BRAIN

2000

\title{
DO WE OWE OUR INTELLIGENCE TO A PREDATORY PAST?
}

\author{
C. K. Brain \\ Emeritus Curator, the Natural History Museum \\ Pretoria, South Africa
}




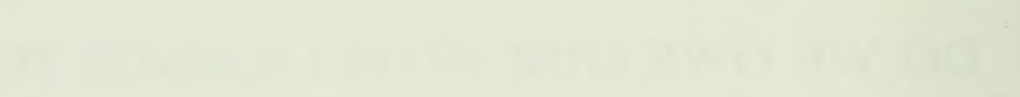

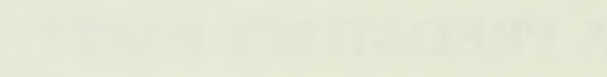




\section{JAMES ARTHUR LECTURES ON THE EVOLUTION OF THE HUMAN BRAIN}

Frederick Tilney, The Brain in Relation to Behavior; March 15, 1932

C. Judson Herrick, Brains as Instruments of Biological Values; April 6, 1933

D. M. S. Watson, The Story of Fossil Brains from Fish to Man; April 24, 1934

C. U. Ariens Kappers, Structural Principles in the Nervous System; The Development of the Forebrain in Animals and Prehistoric Human Races; April 25, 1935

Samuel T. Orton, The Language Area of the Human Brain and Some of Its Disorders; May 15, 1936

R. W. Gerard, Dynamic Neural Patterns; April 15, 1937

Franz Weidenreich, The Phylogenetic Development of the Hominid Brain and Its Connection with the Transformation of the Skull; May 5, 1938

G. Kingsley Noble, The Neural Basis of Social Behavior of Vertebrates; May 11, 1939

John F. Fulton, A Functional Approach to the Evolution of the Primate Brain; May 2. 1940

Frank A. Beach, Central Nervous Mechanisms Involved in the Reproductive Behavior of Vertebrates; May 8, 1941

George Pinkley, A History of the Human Brain; May 14, 1942

James W. Papez, Ancient Landmarks of the Human Brain and Their Origin; May 27, 1943

James Howard McGregor, The Brain of Primates; May 11, 1944

K. S. Lashley, Neural Correlates of Intellect; April 30, 1945

Warren S. McCulloch, Finality and Form in Nervous Activity; May 2, 1946

S. R. Detwiler, Structure-Function Correlations in the Developing Nervous System as Studied by Experimental Methods; May 8, 1947

Tilly Edinger, The Evolution of the Brain; May 20, 1948

Donald O. Hebb, Evolution of Thought and Emotion; April 20, 1949

Ward Campbell Halstead, Brain and Intelligence; April 26, 1950

Harry F. Harlow, The Brain and Learned Behavior; May 10, 1951

Clinton N. Woolsey, Sensory and Motor Systems of the Cerebral Cortex; May 7, 1952

Alfred S. Romer, Brain Evolution in the Light of Vertebrate History; May 21, 1953

Horace W. Magoun, Regulatory Functions of the Brain Stem; May 5, 1954

**Fred A. Mettler, Culture and the Structural Evolution of the Neural System; April 21,1955

**Pinckney J. Harman, Paleoneurologic, Neoneurologic, and Ontogenetic Aspects of Brain Phylogeny; April 26, 1956 
**Davenport Hooker, Evidence of Prenatal Function of the Central Nervous System in Man; April 25, 1957

*David P. C. Lloyd, The Discrete and the Diffuse in Nervous Action; May 8, 1958

**Charles R. Noback, The Heritage of the Human Brain; May 6, 1959

**Ernst Scharrer, Brain Function and the Evolution of Cerebral Vascularization; May 26, 1960

Paul I. Yakovlev, Brain, Body and Behavior. Stereodynamic Organization of the Brain and of the Motility-Experience in Man Envisaged as a Biological Action System; May 16, 1961

H. K. Hartline, Principles of Neural Interaction in the Retina; May 29, 1962

Harry Grundfest, Specialization and Evolution of Bioelectric Activity; May 28, 1963

**Roger W. Sperry, Problems Outstanding in the Evolution of Brain Function; June 3. 1964

*José M. R. Delgado, Evolution of Physical Control of the Brain; May 6, 1965

Seymour S. Kety, Adaptive Functions and the Biochemistry of the Brain; May 19, 1966

Dominick P. Purpura, Ontogenesis of Neuronal Organizations in the Mammalian Brain; May 25, 1967

*Kenneth D. Roeder, Three Views of the Nervous System; April 2, 1968

†hillip V. Tobias, Some Aspects of the Fossil Evidence on the Evolution of the Hominid Brain; April 2, 1969

* Karl H. Pribram, What Makes Man Human; April 23, 1970

Walle J. H. Nauta, A New View of the Evolution of the Cerebral Cortex of Mammals; May 5, 1971

David H. Hubel, Organization of the Monkey Visual Cortex; May 11, 1972

János Szentágothai, The World of Nerve Nets; January 16, 1973

*Ralph L. Holloway, The Role of Human Social Behavior in the Evolution of the Brain; May 1, 1973

*Elliot S. Valenstein, Persistent Problems in the Physical Control of the Brain; May 16,1974

Marcel Kinsbourne, Development and Evolution of the Neural Basis of Language; April 10, 1975

*John Z. Young, What Squids and Octopuses Tell Us About Brains and Memories; May 13, 1976

* Berta Scharrer, An Evolutionary Interpretation of the Phenomenon of Neurosecretion; April 12, 1977

Lester R. Aronson, Forebrain Function in Vertebrate Evolution; April 18, 1978

*Leonard Radinsky, The Fossil Record of Primate Brain Evolution; March 26, 1979 
Norman Geschwind, Anatomical Asymmetry of the Brain in Humans and Animals: An Evolutionary Perspective; April 7, 1980

Irving T. Diamond, Evolution of the Primate Neocortex; March 23, 1981

*Robert D. Martin, Human Brain Evolution in an Ecological Context; April 27, 1982

Eric Kandel, Molecular Explorations into Learning and Memory; April 27, 1983

*Alexander Marshack, Hierarchical Evolution of the Human Capacity; The Paleolithic Evidence; May 1, 1984

Yves Coppens, Environment, Hominid Evolution, and the Evolution of the Brain; April 16, 1985

Roger A. Gorski, Sexual Differentiation of the Brain: from Birds to Rats to Man; April 22, 1986

*Nicholas K. Humphrey, The Uses of Consciousness; April 7, 1987

Stephen J. Gould, Chomsky Under the Spandrels of San Marco; April 5, 1988

*Harry J. Jerison, Brain Size and the Evolution of Mind; October 10, 1989

Paul H. Harvey, Comparing Brains; March 20, 1990

Jeffrey T. Laitman, Evolution of the Vocal Tract and the Origins of Speech; May 7, 1991

*Dean Falk, The Evolution of the Human Brain and Cognition in Hominids; April 14,1992

Alan Thorne, A Biological Basis for the Beginnings of Art? April 26, 1993

Niles Eldredge, Mind Over Matter: The Evolving Place of Humans in Nature; April 11,1994

Este Armstrong, Expansion and Stasis in Human Brain Evolution: Analyses of the Limbic System, Cortex and Brain Shape; April 17, 1995

*Matt Cartmill, Do Horses Gallop in their Sleep? Consciousness, Evolution, and the Problem of Animal Minds; April 30, 1996

John Morrison, The Human Cerebral Cortex: Exceptional Capabilities and Unique Vulnerability; April 8, 1997

*Ian Tattersall, The Origin of the Human Capacity; March 24, 1998

Terrence W. Decon, Primate Mechanisms Underlying Human Brain Evolution; April 7, 1999

*C. K. Brain, Do We Owe Our Intelligence to a Predatory Past? March 20, 2000

*Published versions of these lectures can be obtained from Publications, Dept. of Anthropology, The American Museum of Natural History, Central Park West at 79th St., New York, N.Y. 10024.

**Out of print.

†Published version: The Brain in Hominid Evolution, New York: Columbia University Press, 1971. 


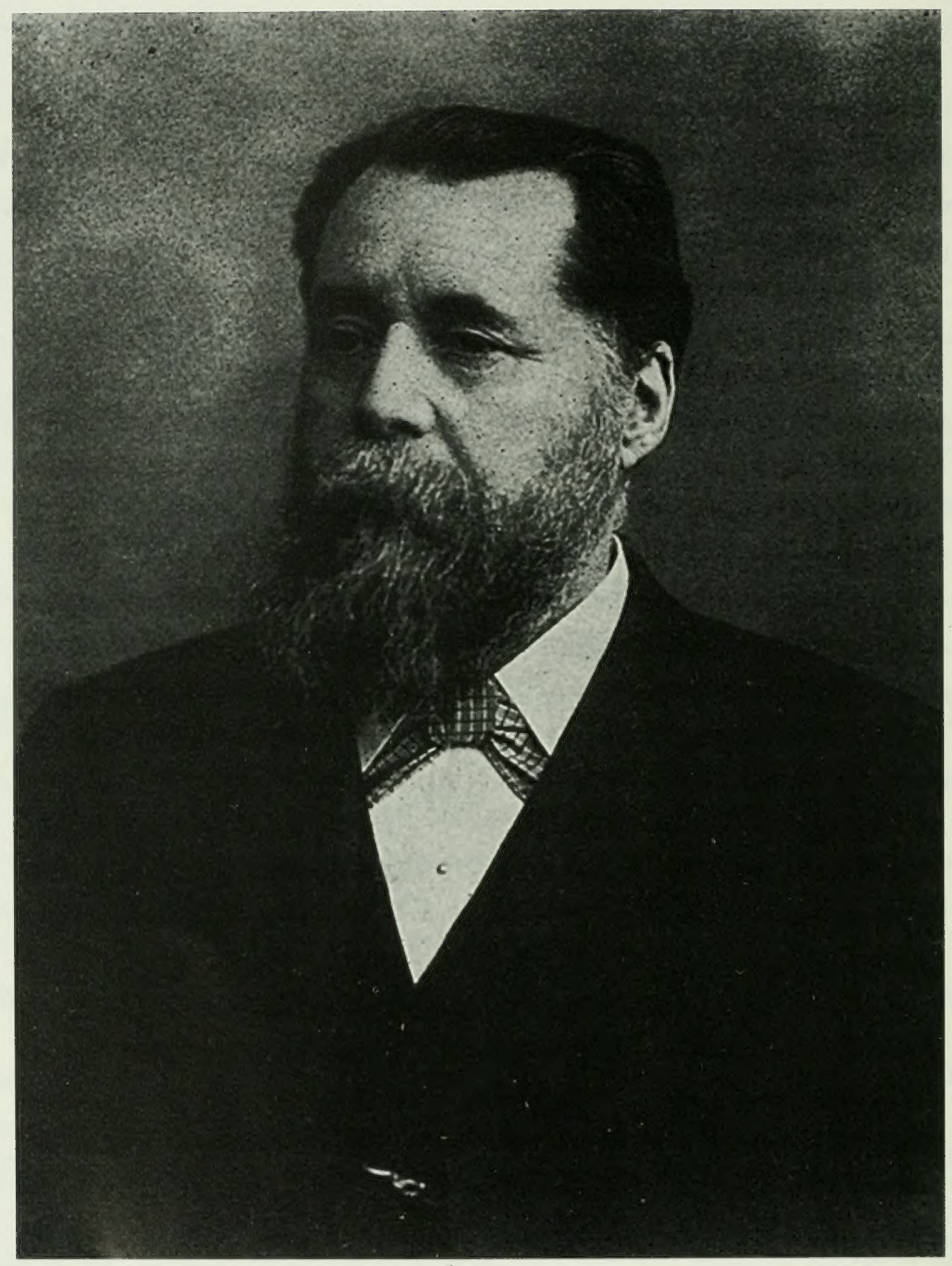

\section{Lames Onttivo}




\section{JAMES ARTHUR}

1842-1930

Born in Ireland and brought up in Glasgow, Scotland, James Arthur came to New York in 1871. Trained in mechanics and gearcutting, he pursued a career in the manufacture and repair of machinery, during the course of which he founded a number of successful businesses and received patents on a variety of mechanical devices. His mechanical interests evolved early into a lifelong passion for horology, the science of measuring time, and he both made some remarkable clocks and assembled an important collection of old and rare timepieces.

Early in the 20th century James Arthur became associated with the American Museum of Natural History, and began to expand his interest in time to evolutionary time, and his interest in mechanisms to that most precise and delicate mechanism of them all, the human brain. The ultimate expression of his fascination with evolution and the brain was James Arthur's bequest to the American Museum permitting the establishment of the James Arthur Lectures on the Evolution of the Human Brain. The first James Arthur Lecture was delivered on March 15, 1932, two years after Mr. Arthur's death, and the series has since continued annually, without interruption. 



\section{DO WE OWE OUR INTELLIGENCE TO A PREDATORY PAST?}

As I am not a neuroscientist, it is an unexpected pleasure for me to contribute a lecture to the James Arthur series on the Evolution of the Human Brain. By contrast, I am an African naturalist, and what I have to say will be very much from the perspective of African cave taphonomy, a recent and rather macabre discipline that uses fossils in an attempt to reconstruct the circumstances of death of the animals involved, as well as to gain insights into their behavior and the paleoecology of the time. The lecture's focus will be on predation, to which I am largely indebted to Professor Raymond Dart, who provoked me into devoting many years of my life developing the principles of cave taphonomy and interpreting the bone accumulations in southern African caves where hominid fossils have been found.

\section{Raymond Dart's Preoccupation with the Process of Predation}

Thirty years after Dart's announcement in 1925 of the first African early hominid that he named Australopithecus africanus, he turned his attention to the Makapansgat limeworks cave in the Northern Province of South Africa. Mining had brought to light numerous fossils, and during the very year of 1925 , a local schoolmaster from a nearby town sent Dart blackened fossil bones from Makapansgat that appeared to have been intentionally burnt. Dart concluded that this must have been "a site of early human occupation" (Dart, 1925b) and when the first hominid fossil was found on the cave's mine dumps, he designated it Australopithecus prometheus. His claim of fire use among these hominids was later disputed by Kenneth Oakley in 1956.

The mining operations at Makapansgat had brought to light a layer of "grey breccia" low down in the sequence of the cave's deposits that contained hundreds of thousands of fossilized bones. Dart arranged for the extraction of over 7000 of these from their travertine matrix and analyzed them as to skeletal part and the kinds of animals from which they came. He found that the vast majority 
was derived from antelope; many came from quite large species and there was a remarkable disproportionate representation in skeletal parts. Some parts were present among the bones preserved and there were curious discrepancies. For instance, in the antelope humerus, overall a very common bone in the assemblage, the distal end was ten times more prevalent than the proximal end. Where animals other than antelope were concerned, such as baboons and hominids, it was common to find only the skull, with no trace of the rest of the skeleton. To explain these curious discrepancies, Dart proposed that the pile of bones had resulted from the exploits of the australopithecines, who he visualized as having been powerful hunters, capable of killing the most dangerous animals of the time. He believed that they brought bones back to their cave shelters, but only the parts that would be useful as tools and weapons. The distal end of an antelope humerus, for instance, made a useful club and so it was retained, while the proximal end, together with various other parts, were discarded at the site of the kill. He developed the concept of an "osteodontokeratic culture" (Dart, 1957a, 1957b) which explains how a large variety of bones would have been used in various ways. In presenting his concept of "the predatory transition from ape to man," he used powerful prose:

On this thesis man's predecessors differed from living apes in being confirmed killers: carnivorous creatures that seized living quarries by violence, battered them to death, tore apart their broken bodies, dismembered them limb from limb, slaking their ravenous thirst with the hot blood of victims and greedily devouring livid writhing flesh. (Dart, 1953)

To explain the fact that the fossil hominids were represented by little more than skulls, Dart proposed that they had been "head hunters" and "professional decapitators," presenting his ideas in a series of 39 publications on the topic between 1949 and 1965. Writing about "the mighty hunters" of Makapansgat, he concluded:

They were also callous and brutal. The most shocking specimen was the fractured lower jaw of a 12-year-old son of a man-like ape. The lad had been killed by a violent blow delivered with calculated accuracy on the point of the chin, either by a smashing fist or a club. The bludgeon blow was so vicious that it had shattered the jaw on both sides of the face and knocked out all the front teeth. This dramatic specimen impelled me in 1948 and the seven years following to study further their murderous and cannibalistic way of life. (Dart, 1956) 
Throughout this project, Dart's style of writing was dramatic and forceful, unlike the kind of writing normally encountered in serious scientific publications. On several occasions, I asked him why he had chosen this particular approach. His answer was direct and simple: "that will get them talking," he said, and he certainly succeeded in his objective. Dart's ideas generated an enormous amount of interest and controversy in scientific and lay circles alike and provoked various people, including myself, to re-evaluate his claims. Another person affected by Dart was the American dramatist and playwright Robert Ardrey who was so captivated by his ideas on early human nature that he wrote a series of books on the topic, starting with African genesis-A personal investigation into the animal origins and nature of man (1961). These works were very influential in stimulating widespread discussion on the behavior of human ancestors.

At the time Dart first presented his conclusions on the "osteodontokeratic culture" at the 3rd Pan African Congress on Prehistory, held in Livingstone during 1955, I was busy with a Ph.D. project on the caves from which the hominid fossils had come. In this connection I had interacted regularly with Dart, particularly with regard to the Makapansgat cave and I was enthralled with his ideas of "the predatory transition from ape to man." I developed three ambitious goals at that time: the first was to analyze, as Dart had done, the fossil accumulations from other hominid-bearing cave sites; the second was to excavate one of those cave deposits myself; and the third was to document the factors responsible for bone accumulations in caves. I had to wait until 1965 for this opportunity to materialize, at which time I was appointed paleontologist at the Transvaal Museum in succession to Robert Broom and John Robinson. I then started on a 25-year-long investigation of the Swartkrans cave and its fossil assemblages, and I will be returning to this episode in the course of the lecture.

When I started to analyze other ancient and modern fossil bone assemblages, it soon became apparent that skeletal disproportions were widespread and the inevitable result of the fact that some skeletal parts survive destructive treatment better than others. As an example, in a sample of modern goat bones discarded by Nama 
Hottentot peoples around their Namib Desert villages of Namibia and then chewed by their dogs, I found 87 distal humerus pieces, but not a single proximal end. The reason was clear: while the distal humerus is a solid, dense piece of bone with a relatively high specific gravity, the same was not true of the upper end. This is a fragile, spongy structure with a much lower specific gravity, and is easily destroyed for the nutrients it contains.

Interestingly enough, the overall survival of goat skeletal parts in the Namib sample (Brain, 1961, 1981a) closely mirrored the figures that Dart had encountered in his sample of antelope bones from Makapansgat, so there was no longer any reason to invoke deliberate hominid selection to explain the discrepancies. Before publishing anything on this finding, I showed the Namib bones and results to Dart and explained the implications for his osteodontokeratic cultural concept. It was obvious that these results undermined the basis of Dart's theory, and for about 10 minutes he was taken aback and perplexed. But after this initial dismay, he became increasingly enthusiastic, saying "this is wonderful-now at last we are getting closer to the truth." Rather than condemning this young upstart who was upsetting his cherished concept, Dart nominated me for an award. I realized then that he was much more interested in the subject of his investigations than in his position relative to them and that he was one of those rare individuals with true generosity of spirit, particularly in this rather emotional field of paleoanthropology.

As the discipline of African cave taphonomy crystallised, more and more of Dart's concepts of "the blood-bespattered archives of humanity" were seriously questioned. It became apparent, for instance, that the Makapansgat bones were more likely to have been collected by striped hyenas than by hominids. Although he freely admitted the accuracy of alternative explanations, I doubt that Dart ever truly discarded his Makapansgat-based concepts entirely. For instance, during the course of our Swartkrans investigation, we found about 60 pieces of bone that had apparently been used as digging tools, the characteristics of which we were able to replicate on modern bones used for that purpose (Brain and Shipman, 1993). I was anxious to show these specimens to Dart and ask for his 
comments, so we invited him and his wife to the Transvaal Museum. Even though he was over 90 years old and almost blind, he felt the shape of each piece between his fingers with obvious excitement. Then he said, "Brain, I told you long ago that Australopithecus made bone tools, but you didn't believe me. Now, what do you think these were used for?" I replied that I was almost certain that they had been used for digging in the ground. His mouth fell open in astonishment and he sat back in his chair with an expression of complete disbelief. "That," he said, "is the most unromantic explanation that I have heard of in my life." He thereupon took the sharpest of the bone tools on the table and stuck it into my ribs, saying, "I could run you through with this." Hence my long-standing fascination with the process of predation.

\section{The Remarkable Phenomenon of Brain Expansion in the Human Lineage and a Probable Reason for its Occurrence}

By any standards, the increase in the size of the brain relative to that of the body in our human ancestors during the last two million years was a remarkable zoological event. When the earliest known members of the Homo lineage appeared on the scene, in the form of $H$. habilis or $H$. rudolfensis, their average brain capacity was about $654 \mathrm{cc}$; this had risen to about $850 \mathrm{cc}$ in $H$. ergaster and $H$. erectus, and to $1400 \mathrm{cc}$ in archaic $H$. sapiens towards the end of the Middle Pleistocene. As Leslie Aiello and Peter Wheeler (1995) pointed out, this event is all the more remarkable because a brain is built of "expensive tissue" - although a human brain may only take up 2 to $3 \%$ of the weight of the whole body, it uses 16 to $20 \%$ of the energy consumed by the resting body. To double the size of the brain relative to that of the body would usually mean that the basal metabolic rate (BMR) of the animal would have to be substantially increased. Oddly enough, this has not been observed in humans, in comparison to related primates, and Aiello and Wheeler concluded, therefore, that human brain expansion occurred at the expense of the size of the gut, which has apparently shrunk during the course of human evolution. To be able to function with a much smaller gut implies that ancestral humans changed to a diet of higher 
quality, such as one including animal protein, and they would have done this by scavenging and active hunting.

It has been customary to think of humans as being unique in so many ways, but this is not always true. When we look at brain weight relative to that of the body, our percentage is half that of squirrel monkeys of the genus Saimiri from South America; and turning to energy consumption of the brain relative to that of the whole body, we find that some mormyrid fishes show a figure three times higher than our own (Nilsson, 2000).

Clearly, a greatly increased brain size is not a luxury to be acquired lightly. It is something that would only have evolved under strong selective pressure, but of what did this pressure consist? For many years it has been suggested that brain expansion, and the benefits that this brings to humans, has been linked to the problems of making a living in the changed and more open habitats that characterized Africa during the last two million years. Frequently cited is the need to cope with more complex foraging strategies than had been the case when ancestral hominids lived in evergreen forests. I have no doubt that this need would have been one of the factors. The proposal that I will be putting forward in this lecture also relates to survival in alien habitats, but focuses on the need to outlive the ever-present threat of predation by carnivores in those habitats. It seems to me that predation could constitute a large part of the selective pressure required to promote the evolution of human brain expansion. The predation in this case was uniquely an attribute of the African habitats in which representatives of the genus Homo evolved. But before turning to those habitats themselves and the predators that they harbored, let us consider briefly how such new habitats came into being.

\section{Cenozoic Cooling and its Effects on African Habitats}

It has become clear that a critical factor in the appearance of more open habitats in tropical and sub-tropical Africa was a global cooling trend. During 1979, I was invited by the Geological Society of South Africa to give one of the Alex. L. Du Toit Memorial Lectures and decided to explore the topic The evolution of man in Africa-was it 
a consequence of Cenozoic cooling? (Brain, 1981b). This was an early attempt to correlate some of the important episodes of human evolution with climatic events, which formed part of a long-term cooling trend over many millions of years. My attention had been drawn to this particular topic in the course of our Swartkrans cave investigation where we found that repeated cycles of erosion were interspersed with ones of deposition. As it seemed likely that these cycles were climatically mediated, I started to familiarize myself with the published record of temperature changes and to speculate on how they might have affected African habitats, as well as the fauna and flora within them. It seemed as if some interesting correlations were possible, not only for human evolution, but for that of other mammals as well. At that time, Elisabeth Vrba was working at the Transvaal Museum and she took up this topic with her usual energy and enthusiasm; with various colleagues, she organised several international conferences that resulted in many new publications that clarified the issues involved.

Early in the 20th century, geologists realized that a remarkable record of the Earth's history had been preserved in deep-sea sediments, steadily accumulating in a protected environment under water up to $3 \mathrm{~km}$ in depth. Samples of the sediments retrieved by deepsea drilling frequently contain the calcareous shells, or tests, of foraminiferans, which had been studied taxonomically throughout the century, and of which water temperature preferences were generally known. It is also possible to say which species were planktonic, living in surface waters, and which were benthic, living on the ocean floors. So the various species present in a sediment core gave some indication of the sea temperature at the time they lived. But a far more precise method of estimating past sea temperatures could be gained from determining the proportions of oxygen isotopes in the shells of foraminiferans, a method first used by Cesare Emiliani (1955). The oxygen in the calcium carbonate of foraminiferal tests consists of two isotopes: oxygen 16 , the more common one, and oxygen 18, about 500 times less common. Thermodynamic theory predicts that the ratio of these two oxygen isotopes in carbonate, such as that of foraminiferal shells, will vary according to the temperature at which the mineral was deposited. For this reason, mea- 
surements of the isotope ratios in the shells gives an indication of the temperature at which the forams lived. In relating isotope ratios to temperature, however, it is essential to know what the isotopic composition of the seawater itself was, and this is complicated by the so-called ice-volume effect. Its basis is that when water is vaporized from the surface of the ocean, the lighter of the two isotopes is preferentially taken up into the water vapor, leaving the sea enriched in the heavier one. When the water vapor is deposited on a continent as snow, for instance, this land-based ice will remain enriched in lighter isotopes at the expense of the surrounding ocean. This large-scale build-up of terrestrial ice caps will result in an enrichment of seawater with oxygen 18. Clearly, the two signals are closely related, but there has been a great deal of discussion as to which would provide the more reliable temperature record. Only very recently has it become possible to separate the global ice-volume effect from the pure temperature effect in benthic foraminiferal tests by using the magnesium/calcium ratio in the calcite of these tests (Lear et al., 2000). The new curve showing the decline in deep sea temperatures during the last 50 million years is surprisingly similar to that published by Shackleton and Kennett in 1975 indicating an overall temperature drop during this period of about $12^{\circ}$ Celsius. Of particular interest to this discussion is the conclusion that an ice cap first developed in east Antarctica about 34 million years ago.

Based on other evidence, it seems likely that the cooling trend may be attributed largely to continental drift following the breakup of the supercontinent Gondwanaland, which initially embraced South America, Africa, Antarctica, and Australia. When Antarctica took up its south polar position, other continents drifted away from it to the north, and an open seaway was created around its periphery. This started the Circum-Antarctic Current driven by the rotation of the earth and the resultant westerly winds. Once this happened, the thermal isolation and refrigeration of Antarctica began.

As far as African habitats go, the global cooling trend seems to have crossed a critical threshold about 6.5 million years ago with the "Terminal Miocene Event." At about this time a widespread sea-level drop has been recorded and this, in addition to tectonic movements in the Gibraltar area, resulted in the isolation of the 
Mediterranean from the Atlantic. The seawater in the Mediterranean basin then dried out completely, depositing over one million cubic kilometres of sea salt, which, as Ryan (1973) pointed out, constitutes about $6 \%$ of the dissolved salts in the world's oceans; its removal from circulation must have resulted in a significant freshening of sea water that would have facilitated the formation of sea-ice near Antarctica. The Messinian salinity crisis had striking physical and biological consequences, as were first described by Hsu et al. (1977). For instance, a dry-land connection was opened between Africa and Europe, facilitating the free exchange of fauna and flora, while the cool, arid climate around the desiccated Mediterranean might well have promoted an early expansion of African savannas (Brain, 1984). The evidence further suggested that the connection between the Atlantic and the Mediterranean Oceans was re-established abruptly at about 5 million years ago, which brought the salinity crisis to an end.

It had long been surmised that the Terminal Miocene Event was precipitated by the sudden establishment of the west Antarctic ice cap and its linkup with the long-standing east Antarctic equivalent. While this concept still seems to be current, the situation has been complicated by evidence of tectonic activity, active rifting, and the rise of the Transantarctic Mountains (Denton, 1995, Cande et al., 2000).

The next important event in the cooling trend was the onset of the first Northern Hemisphere glaciation, which is currently placed at about 2.54 million years ago (Clark et al., 1999). This trend was accompanied by the regular glacial-interglacial cycles that have been such a prominent feature of more recent times, first with a periodicity of 41 thousand years until about 1 million years ago, followed by the establishment of the 100-thousand-year cycles, into which we are still currently locked. In Africa, the effects of cooling on habitats was greatly enhanced by volcanic activity and tectonic movement; in East Africa, combined effects of the rift valley development, associated volcanoes and regional uplift were striking, while, in southern Africa, uplift of between 600 and 900 meters along the eastern regions may have had as much effect itself as the superimposed global cooling trend (Partridge et al., 1995). 
Figure 1 shows an attempt I made in 1979 to correlate some features in hominid evolution with low-temperature episodes. The hominid phylogenetic tree, as visualized then, was very simple in comparison with any present day representation accommodating the numerous new hominid taxa described during the last 20 years. As Ian Tattersall (2000) has commented, our present situation of being the only living hominid on earth is an unusual one; at any time during the last few million years, several hominid taxa are likely to have shared their habitats. The speciation that we observe in hominid and other vertebrate lineages during the Plio-pleistocene in Africa has almost certainly resulted from habitat fragmentation and the isolation of small population groups. That open country was becoming an important issue in this regard is clearly indicated by Elisabeth Vrba's work (1995) on the first documented appearance of 37 new antelope species, many of them open country grazers, between 2.7 and 2.5 million years, at a time when the robust australopithecine lineage split from that leading to Homo.

Some of the Dangers Inherent in More Open African Habitats and the Need for Safe Sleeping Sites

My emphasis here will be on predators known to have existed in southern African savannah and grassland environments during the last two million years, particularly those that would have posed a threat to the security of hominids. Most of these animals are also known to have existed further north in the continent, so they would have interacted with the hominids whose fossil bones have been found at the East African sites. In comparison to evergreen forests, savannah environments certainly harbour a far wider range of carnivore species dangerous to hominids; but this is not to say that the traditional forest habitats were without their hazards. Leopards, for instance, have an extraordinarily wide habitat tolerance-from open desert environments to tropical forests - and would certainly have preyed on hominids before they left the forests. Other significant predators would have been among the forest eagles, such as today's Crowned Eagle, Stephanoaetus coronatus, although we do not have information on its fossil history. It has been suggested (Berger and 


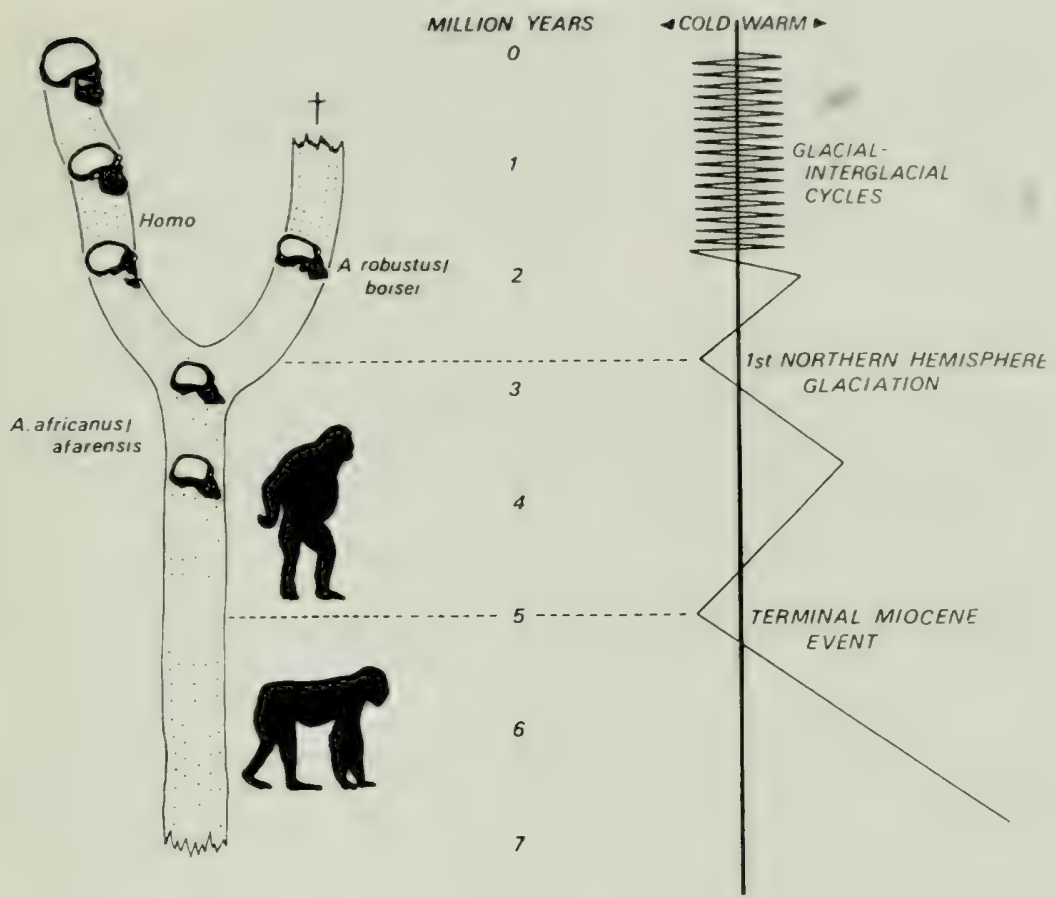

Fig. 1. An early attempt (Brain, 1981b) at a correlation between events in hominid evolution and low-temperature episodes. The Terminal Miocene Event is correlated with the acquisition of erect posture and with the separation of the African great ape lineage from that of the australopithecines. (The split is not shown here.) The first Northern Hemisphere glaciation is correlated with the separation of the Homo and robust australopithecine lineages.

Clarke, 1995) that a Crowned Eagle was the predator responsible for killing the Australopithecus africanus child at Taung. In this regard, an interesting report appeared recently (Brightman and Westrop, 1999) relating how a Crowned Eagle attacked a five-year-old African girl in Zimbabwe, grabbing her in her shoulder and neck with its talons. Although the eagle flapped furiously, it was prevented from taking off with its prey by the fact that the girl managed to grip the wire strands of a fence with both hands and the eagle was killed when it was hit on the head with a stick wielded by an alarmed adult. The child was lucky to survive and this incident 
shows that eagles of this nature will take surprisingly large preyin this case, the victim weighed $19.6 \mathrm{~kg}$.

Some of the potentially dangerous carnivores known in southern Africa from Swartkrans Member 1 times onward, particularly in savanna-grassland environments, will now be briefly considered.

\section{Family Felidae}

Subfamily Felinae: the true cats

Panthera pardus Linnaeus, 1758. The leopard

Particularly well represented in the earlier Swartkrans members, as well as at other sites, apparently very little different then from contemporary leopards, although slightly smaller.

Felis crassidens Broom, 1948. The crassidens cat

Initially described from Kromdraai A, this remarkable short-faced cat of leopardlike proportions had skull characteristics of both a leopard and a cheetah.

Panthera leo (Linnaeus, 1758). The lion

Fragmentary fossil remains of lions have been found at several of the hominid-bearing cave sites and these are tentatively assigned to the modern lion taxon, although they seem to indicate a rather more robust carnivore than the contemporary lion.

Dinofelis barlowi (Broom, 1937). The false saber-tooth cat

The regular occurrence of fossils of this remarkable cat in the South African cave deposits suggests that it may have frequented caves as lairs. The most striking feature of Dinofelis is the considerable enlargement of the upper canines. which, however, were not laterally flattened as in the true sabertooths. On the basis of particularly well-preserved fossil specimens from the Langebaanweg site in the western Cape, Hendey (1974) wrote, "Dinofelis was evidently a heavily built animal, with the fore and hind feet, and perhaps the limbs in general, being more equally proportioned than in either the leopard or cheetah, and possessing a relatively short tail. Its locomotion is likely to have been ambulatory."

Subfamily Machairodontinae: the saber-tooth cats

Although a variety of saber-tooth cats is known to have occurred in southern Africa prior to two million years ago, only one species makes a regular appearance in the cave deposits after that time:

Megantereon whitei (Broom, 1937). White's saber-tooth

The upper canines of this remarkable predator were long, recurved and strongly flattened from side to side. Its forequarters and neck muscles were very heavily built, suggesting that this was an ambush-killer of large prey. According to Martinez-Navarro and Palmquist (1996), White's sabre tooth colonised Europe from Africa, as far north as the 40th parallel, at the Plio- 
Pleistocene boundary, and is found at a number of fossil localities there. They speculate that its presence may have facilitated meat scavenging by early humans wherever they occurred together, as the saber tooth would have brought down large prey and then left a good deal of meat uneaten, due to its inability to chew bones. Thus of all the dangerous predators, this one must have been a mixed blessing to the early hominids.

\section{Family Hyaenidae}

Chasmoporthetes nitidula (Ewer, 1955). The hunting hyena

An interesting animal, known from Swartkrans Member 1, where it was previously put into the genus Euryboas. It combined hyenid characteristics in its skull and dentition with very long, slender legs, reminiscent of the cheetah. Indications are that it was a fast, cursorial hunter and must have posed a considerable danger to hominids moving about in open country.

Hyaena brunnea Thunberg, 1820. The brown hyena

Fossil representatives of the extant brown hyena are known among the fauna from Swartkrans Member 1. These hyenas both scavenge and hunt and could have been dangerous to hominids, particularly juveniles that may have strayed from the protection of the group.

Crocuta crocuta (Erxleben, 1777). The spotted hyena

Fossils that have been placed in various taxa in the past, but which can probably be attributed to the living spotted hyena taxon, are known from various southern African cave sites. Like the brown hyenas, these were both scavengers and hunters and would certainly have posed a threat to unprotected hominids at night.

\section{Family Canidae}

Lycaon atrox Broom, 1948. The hunting dog

Known from Swartkrans Member 2 and Kromdraai A, this form appears to have been an ancestor of the contemporary Hunting Dog, L. pictus, familiar today as highly effective pack-hunting predators of great speed and endurance. For hominids moving about in open grasslands, these could have been an ever-present threat.

Apart from the mammalian predators listed here, and doubtless many others not mentioned, further dangers would have been posed by crocodiles lying in wait whenever a hominid band went down to a river to drink.

There can be no doubt that hominids would have been constantly vulnerable to predation in these habitats, as baboons still are today, and this would have been particularly true during the hours of darkness. In fact, one can be sure that the availability of secure sleeping sites would have been a prerequisite for the occupation of any area. 
My personal observations show that, although the overall distribution of baboons in southern Africa during historic times was very wide, this was limited on a more detailed scale by the presence of suitable sleeping places. These could be in the form of large trees, inaccessible ledges on cliffs or caves and, in the Sterkfontein valley area, I was able to document the use of dolomite caves as baboon sleeping sites during the frosty winter months on this highveld grassland (Brain, 1981a). As a result of the long and multifaceted Swartkrans investigation, we came to the conclusion that this cave had been used by hominids as a sleeping shelter, as will be described shortly. However, this by no means made them immune to nocturnal predatory danger from time to time.

\section{An Overview of the Swartkrans Cave and its Taphonomic Interpretation}

In 1947, Robert Broom and John Robinson were conducting their fossil search at Sterkfontein and found the well-known skull of Australopithecus that became known as "Mrs. Ples." But, after this, the prospects in the "Type Site quarry" of Sterkfontein did not look favorable and they moved their field team in 1948 across the valley to Swartkrans, where fossil-rich breccia was exposed on the hillside. This proved immediately productive of remains of robust australopithecines, and a mandible of a more advanced hominid, initially described as as Telanthropus capensis (Broom and Robinson, 1949), but later transferred to Homo erectus (Robinson, 1961), also came to light. In fact, this was the first demonstration of the coexistence of Homo and Paranthropus - one that is now known to have persisted for over a million years. A varied fauna was found to accompany these hominids. These excavations exposed a thick seam of pure white stalagmite along the north wall of the cave, which was claimed by a local lime miner who spent the next year blasting it out. Broom died in 1951 and shortly thereafter, the site was abandoned.

Although I had done a geological investigation there in the $1950 \mathrm{~s}$, my paleontological investigations at Swartkrans started in 1965 and it soon became apparent that much earlier, extensive lime mining 
had. in fact, taken place there during the 1930s. My first seven years of the new Swartkrans project were spent in supervising the removal of miners rubble from the cave's environs, sorting it and recovering whatever fossils were to be found, although these obviously lacked stratigraphic information. This interlude gave me the opportunity of doing wide-ranging studies on cave taphonomy and on the characteristics of carnivore food remains. Once clear of rubble and natural hillside-soil overburden, it became apparent that we were dealing with a cave deposit about 45 meters in both east-west and northsouth dimensions, with a vertical shaft at the northeast corner, that led down into "the lower cave." This ramified beneath the north wall of the fossil cavern and had connections upward to the latter. To our surprise, we found that the heavily calcified breccia from which Broom and Robinson had obtained nearly all their fossils represented an isolated block attached to and hanging from the cave's north wall. This became known as the "Hanging Remnant" and it provided a useful clue to the understanding of the very complex relationships of the deposits within the cave. As the excavation proceeded, I searched for several years for the remnants of an earlier deposit on which the Hanging Remnant sediment must have rested before being undercut by erosion. Eventually we found this as a talus cone of calcified cave earth that had accumulated below a longgone entrance above the cave's south wall.

It transpired that the extraordinary complexity of the cave filling had resulted from repeated cycles of deposition and erosion that had passed through the cavern. One is inclined to think of caves as stable repositories of sediment, slowly building up from floor to roof, but typically, this is not the case with the dolomitic caves of the Sterkfontein valley. The usual situation here is that a cavern opens upward to the surface of the hillside, while also having connections downward to lower caverns. This was certainly the case at Swartkrans, with the fossil-bearing sediments resting temporarily on a "shelf" below a sequence of upward-leading entrances, and then being carried away, in part or whole, by erosion into lower caverns. The result is an intricately interwoven set of deposits of different ages, each separated from the next by an erosional interval. It was, in fact, when I realized that such cycles were sure to have been 
climatically mediated that I started reviewing evidence for the Cenozoic cooling mentioned earlier.

The erosion of perhaps 50 metres of dolomitic hillside above the cave, together with the upper part of the cave-filling itself, has doubtless removed a good deal of the evidence for stratigraphic complexity at Swartkrans. But what is left, and came to light during our excavation, indicated five depositional members, each separated from adjacent neighbors by erosional discontinuities. The earliest of these is designated Member 1 Lower Bank, followed by Member 1 Hanging Remnant, Member 2, and Member 3. All of these have remains of robust australopithecines in them and are thought to vary in age from 1.8 to 1 million years. Member 4 is a Middle Stone Age deposit with abundant stone artifacts, but little bone, while Member 5 appears to be about 11,000 years old, with a fossil assemblage suggestive of the food remains of leopards.

Although the fossil sample from the Hanging Remnant that resulted from the early excavation of Broom and Robinson has many superb hominid fossils in it, its use is limited from the perspective of taphonomic interpretation. The extremely hard matrix was first dislodged with dynamite and the resulting blocks were then broken up with hammers. When an interesting-looking fossil was broken through, particularly if it was a cranial piece, it would be kept for subsequent preparation, but many other bones were simply discarded onto the dump. Although we systematically searched through the excavation dumps, recovering some specimens, many others had been carried away in the intervening years by casual visitors to the site. The final Hanging Remnant sample was therefore biased in favor of cranial pieces and, very probably, in favor of primates at the expense of less spectacular mammals. Described in detail elsewhere (Brain, 1981a), the assemblage was found to consist of 2,381 bones from 41 identified taxa, shown diagrammatically in figure 2 . Primates-baboons and hominids - made up $47 \%$ of the total number of individuals - followed in abundance by ungulates (35\%) and carnivores $(12 \%)$.

By contrast, our excavation in the Lower Bank of Member 1 yielded a total of 153,784 pieces of fossil bone that were analyzed in detail by Virginia Watson (1993). Of the animals that had con- 
tributed to this collection, she found that primates-baboons and hominids-made up $21 \%$ or less than half that in the Hanging Remnant sample. The figure for Member 2, based on a sample of 70.52 4 fossil pieces, was rather similar at $25 \%$.

Concerning these four species of baboon and two of hominid, which naturally showed a wide range of body weights, it was interesting to observe that those species with the greatest body weights also had the highest proportion of juveniles represented among their fossils. Furthermore, cranial remains were disproportionately common in relation to other skeletal parts and we were faced with "the mystery of the missing bodies." An obvious possibility was that we were dealing with the food remains of a carnivore, such as a leopard, with a preferred prey size, and this suspicion was confirmed by the specific damage that some of the bones had suffered (Newman, 1993). One well-known specimen, the calvaria of a hominid child, was found to have two punctures in its parietal bones and the distance between these was matched by the spacing of the lower canines of a fossil leopard from the same part of the cave. The reconstruction that I suggested was that the child had been killed by a leopard, perhaps by the usual throat-bite method, and that it had then been picked up by its head, as leopards are inclined to do, and dragged off to a feeding place within the dark recesses of the cave. This carrying behavior, observed in contemporary leopards with monkey or baboon prey, results in the upper canines gripping the face of the prey, while the lower canines penetrate the back of the skull.

The detailed taphonomic analysis of the fossil assemblages from Swartkrans Members 1 and 2 suggested that hominids and baboons came to shelter within the entrance area of the cave on cold winter nights and that they were preyed upon there by leopards and sabertooth cats. The predators took their victims to the lower parts of the cave and ate them; what scraps survived their attention, and that of the scavengers such as hyenas-whose coprolites in the deposits testify to their visits - contributed to the fossil assemblage.

In broad perspective, my impression is that the life of hominids in environments such as that of the Sterkfontein valley one and a half million years ago would have been a hazardous one, calling for 


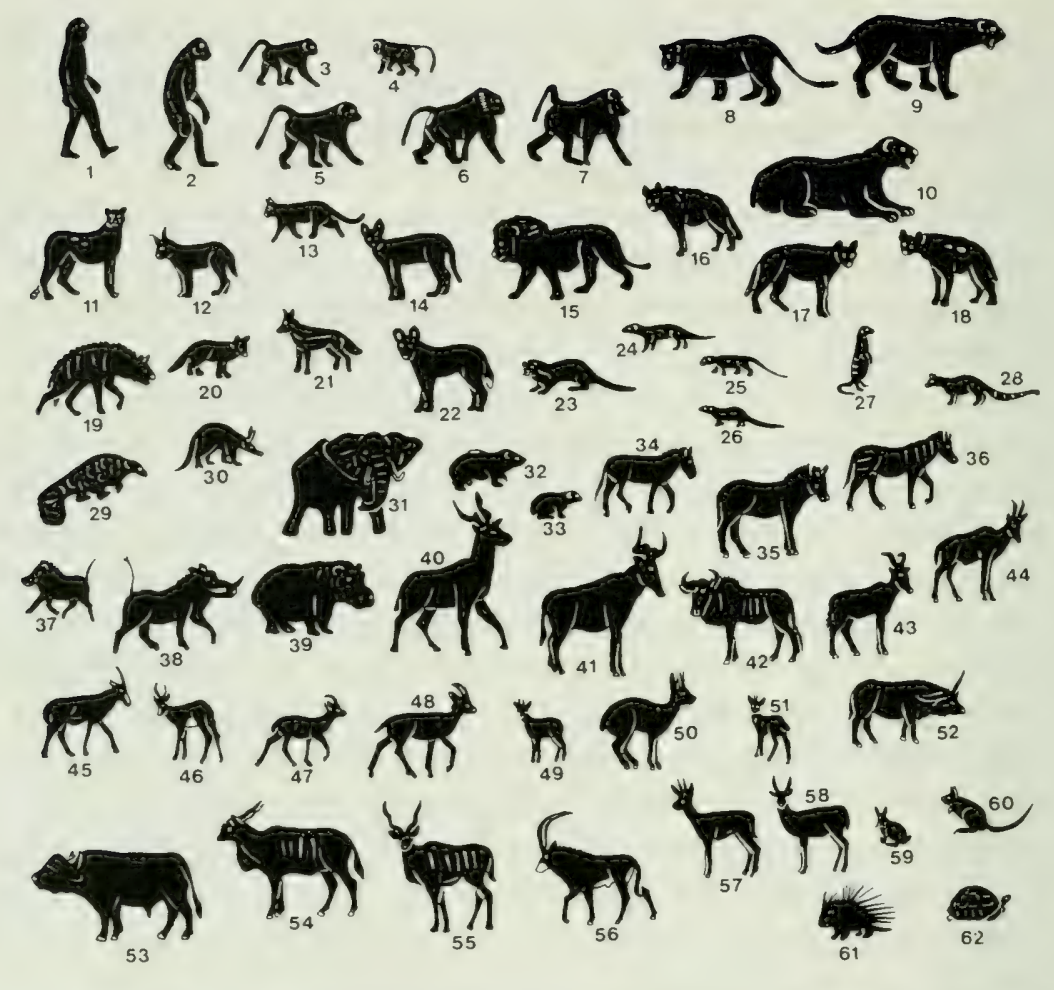

1: Homo erectus (man) 1,3,2,0. 2: Australopthecus robustus (robust apeman) 13,87,17,9. 3: Parapapio jonesi 0,8,0.0. 4: Cercopithecoides sp. 1, 0,0,0.5: Papio hamadryas robinsoni $6,38,8,11$. 6: Theropithecus oswaldi danieli $1,17,1,4.7$ : Dinopithecus ingens $1,26,0,0$. 8: Panthera pardus (leopard) 4,12,2,5.9: Dinofelis sp. (faise sabre loothed cat) 0,1,0,0. 10: Megantereon sp. (dirk-toothed cat) 0,1,0,1 11: Acinonyx jubatus (cheetah) 0,1,0,1.12: Felis caracal (caracal) $4,0,0,0$. 13: Felis lybica (Wild cat) $0,0,0.1 .14$ : Felis serval (Serval) 1,0,0.0. 15: Panthera leo (lion) 1,1,0,0, 16: Hyaena brunnea (brown hyaena) 1.4.2.3.17. Chasmaporthetes mitdula (hunting hyaena) 2,8,1,2. 18: Crocuta crocuta (spotted hyaena) 0,2.1,1. 19: Proteles sp. (large fossil aardwolf) 1,1,0,1. 20: Vulpes sp. (fox) 0,2,0,3. 21: Canis mesomelas (black-backed jackal) 3,4,4,5. 22: Large canid gen. and sp. indet. 0,0,1,1.23: Aonyx capensis (clawless otter) 2,0,1,2. 24: Attax sp. (water mongoose) 0,0,1,1. 25: Cynictis penictllata (yellow mongoose) 0,0,1,1, 26: Herpestes ichneumon (large grey mongoose) 1,0,0,0.27: Suricata suncatta (suncate) 0,0,2,1. 28: Genetta tigrina (large-spotted genet) 0,0,0,1.29: Manis sp. (pangolin) 0.0.0.1. 30: Orycteropus afer (antbear) 1.0,1.1.31: of Elephas sp. 2,0.0.1.32. Procavia transvaalensis (large fossil dassie) 3.8.3.5. 33: Procavia antiqua (tossil dassie) 17, 16, 10,11. 34: Hipparion lybicum steyleri (three-toed horse) 1,1,1,1. 35: Equus capensis (giant Cape horse) 2,6.3.5. 36: Equus burchelli (Burchell's zebra) 0,0.0.1. 37: Phacochoerus sp. (wanthog) 1,0.3.1. 38: cf. Tapinochoerus meadowsı (large fossil pig) 1,7,1,1. 39: Hippopotamus sp. (hippopotamus) 1,0,0,1. 40: Girrafıd 0,1,1,1. 41: Megalotragus sp. (giant hartebeest) $0,3,1,3.42$ : Connochaetes sp. (wildebeest) 7,19,7,17. 43: Medium alcelaphine: Alcelaphus sp. of Beatragus sp (hartebeest) 3.22,3,6. 44: Rabaticerus porrocomutus 0,2,0.0. 45: Damaliscus Sp. (blesbuck) 2,4,6.6. 46: Antidorcas marsupialis/austrahis (springbuck) 11,0,10,18. 47: Antidorcas recki 0,6.2.1. 48: cf. Gazella sp. (gazelle) 5,6,5,14. 49: Oreotragus oreotragus (klipspringer) 1.0.0.1.50: Oreotragus major (fossil klipspringer) 0,1,0,0.51: Raphicerus campestris (steenbuck) 1,0,1,3.52: Makapania sp. (musk ox) 0,3.0,0. 53: Syncerus sp. (buttaio) 2,3,2,3. 54: Taurotragus oryx (eland) 0,0,1,1.55: Tragelaphus strepsiceros (kudu)

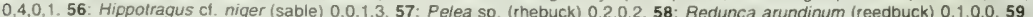
Lagomorph gen. and sp. Indet. (hare) 9,0,4,7,60: Pedetes Sp. (springhare) 1,0,1,1.61: Hystrx africaeaustralis (porcupine) 2,2, 1,2 62: Chelonia indet. (tortoise) 1.0.2.2

Fig. 2. A chart of the larger vertebrates whose remains are represented in Members 1-3 at the Swartkrans cave (Brain and Watson, 1992). Figures after each taxon represent minimum numbers of individuals represented in the fossil remains from the Lower Bank (Member 1), Hanging Remnant (Member 1), Member 2, and Member 3 , respectively. 
continual vigilance against a wide variety of predatory threats, day and night. In my opinion, such threats must have represented a significant selective pressure in favor of any advance in intelligence and resulting technology that could have reduced the threat. But it is not only among hominids that predation appears to have driven the course of animal evolution. How long has the process of predation been a factor in the evolution of animal life? To answer that, let us go back in time to the very beginnings of animal life.

\section{The Ancient Roots of Predation}

The evidence at Swartkrans convinced me of the importance of predation to the evolution of intelligence and I was keen to know more of the ancient roots of predation among the earliest animals. It is well-known that remains of animals date back to Terminal Proterozoic times, almost 600 million years ago, and some of the best evidence in this regard can be found in sediments belonging to the Nama Group in Namibia that were accumulating in a shallow sea on the western edge of the Kalahari Craton at the time of the assembly of Gondwanaland (Brain, 1997b). It is to the fossil record from the Nama Group, as well as from the somewhat older Otavi Group on the Congo Craton further to the north, that I have given my attention in the last few years.

Late Proterozoic times, when animals first left abundant traces in the fossil record, were preceded by several very severe glacial periods. Glacial deposits from two of these episodes, each with their very distinctive "cap-carbonates," have been recognized in northern Namibia (Hoffmann and Prave, 1996), as well as elsewhere in the world. Based on these, Paul Hoffman and his colleagues (1998) have invoked the "snowball earth" scenario, first proposed for earlier Precambrian low-temperature episodes by Kirchvink (1992). The concept addresses the problem of low-latitude glaciations, as are indicated by the Namibian evidence, and proposes that the oceans froze over and that biological productivity collapsed for some millions of years. It was only through the abundant production of carbon dioxide by active volcanoes that a "greenhouse" situation developed, rapidly melting the global ice and swinging the climate to 
an opposite extreme, as indicated by the cap-carbonates immediately above the glacial sediments.

The period following the last of these glacials, starting at about 600 million years ago, saw two remarkable radiations of animal life (Conway Morris, 1993). The first of these is known as the Ediacaran radiation and involves soft-bodied organisms whose remains are typically preserved in sandstones. The first evidence of these turned up in the Nama basin of southern Namibia as early as 1908, and was described by Gürich in 1933. These organisms were typically flat or leaflike with a very characteristic quilted structure, reminiscent of an air mattress, but there were also circular, medusoid-like structures. A similar fauna came to light in 1946 in the Ediacara Hills of South Australia and it is from this locality that the radiation gained its name. Since then, similar fossils have become known from at least 30 localities on 5 continents (Narbonne, 1998).

The remarkable structure shown by these organisms prompted Seilacher (1992) to create a new Kingdom, the Vendobionta, for them and he wrote that they were,

immobile foliate organisms of diverse geometries that were only a few millimetres thick, but reached several decimetres in size. A shared characteristic is the serial or fractal quilting of the flexible body wall, which stabilised shape, maximised external surface and compartmentalised the living content. Since no organs can be recognised, this content is thought to be a plasmodial fluid rather than multicellular tissue. (Seilacher, 1992)

In a later development of this concept, Buss and Seilacher (1994) put forward the hypothesis that the Vendobionta should be regarded as a phylum, rather than a Kingdom, constituting a monophyletic sister-group of the Eumetazoa. They speculated that the Vendobionta were cnidarian-like organisms that lacked stinging cells, or cnidae, and that cnidarians arose later through acquisition of cnidae by symbiosis with microsporidians. In this view, Ediacaran fossils are not thought to have been ancestors of living coelenterates, but rather, represented a failed experiment in the history of animal life.

The affinities of Ediacaran organisms have been the subject of vigorous debate in the last 20 years, but whatever they actually were, it is now clear that this fauna existed for about 55 million years, showing maximum diversity during the last 20 million (Narbonne, 
1998). The most recent organism of this kind, described as Swartpuntia germsi by Narbonne et al. (1997) from southwestern Namibia, comes from just below the Cambrian boundary and has been dated at about $5+3$ million years. It consists of quilted, leaflike "petaloids," each reminiscent of the Australian form Dickensonia, but attached to a central stalk. Like other members of this fauna, Swartpuntia presumably absorbed nutrients directly from the water and possibly made use of photosynthetic or chemosynthetic symbionts.

The Ediacaran community was apparently composed of sedentary or very slow-moving individuals luxuriating in a tranquil "Garden of Ediacara," as Mark McMenamin (1986) has termed it. However, there was indications even then that this could not last. At least one of the organisms, described originally from Australia as Kimberella, but now well documented from White Sea sediments in Russia (Fedonkin and Waggoner, 1997), is interpreted as having molluscan affinities. It is characterized by a single unmineralized shell and seems to have grazed on the algal biomat that characterized the shallow seafloors at that time (Seilacher, 1999). Also attached to this biomat were small cone-in-cone structures, originally described by Gerard Germs (1972) from the Nama basin as Cloudina. These have been found in many parts of the world, and is regarded as a Terminal Proterozoic index fossil (Grant, 1990). The cones presumably housed a filter-feeding metazoan, of at least cnidarian-grade organization, with tentacles protruding from the top. Of particular interest is the fact that many Cloudina fossils from China studied by Bengtson and Zhao (1992), show evidence of having been bored into by predators. They wrote,

Cloudina, the earliest known animal to produce a mineralized exoskeleton, shows evidence of having been attacked by shell-boring organisms. Of more than 500 tubes from Shaanxi Province. China. 2.7\% have rounded holes 40 to 400 micrometers in diameter. The relation between the size of the holes and the width of the bored tubes suggests that the attacking organism was a predator, selecting its prey for size. If true, this would be the oldest case of predation in the fossil record and would support the hypothesis that selection pressures from predation was a significant factor in the evolution of animal skeletons around the Precambrian-Cambrian boundary. (Bengtson and Zhao, 1992)

Recently, I have come across similarly bored Cloudina tubes from the Nama Basin, and these will be described shortly. 
The appearance of this first predator anticipated the end of the tranquil Garden of Ediacara. The end came with the second major radiation of those times, the "Cambrian explosion of animal life," so well documented in the fossils of the Burgess Shale and other sites such as those at Chengjiang in China. These fossils suggest that within a brief period of geological time, representatives of almost every known phylum of animal life made their appearance in Middle Cambrian seas. Among these animals were, of course, burrowers and grazers, which rapidly destroyed the microbial biomats that had been such a feature of shallow seas for three billion years; with their introduction came what Seilacher (1999) has termed the "agronomic revolution."

But of particular relevance here was the appearance, with the Cambrian radiation, of the first effective predators that the world had seen. By definition, an animal is a multicellular heterotrophan organism that feeds on other living things or their remains, while predators form but a subset of these. Even in the earlier Ediacaran days, Kimberella was acting as a true animal, grazing off the algal biomat. But to feed on other true animals will generally requires active pursuit and the overpowering of reluctant prey. For this coordinated mobility and the ability to locate evasive prey are required. In other words, what are needed are sense organs.

Predators obviously rely on a variety of senses, but for the present purpose, let us consider just one, that of sight. The largest and most fearsome of the Cambrian predators was Anomalocaris, growing up to $50 \mathrm{~cm}$ long and known now from a variety of localities in different parts of the world. The expanded lateral lobes along the length of the body made it an active swimmer, while the two powerful appendages anterior to the mouth must have been effective in the capture of prey, such as trilobites. These appendages had, in fact, been described (Whiteaves, 1892) many years before the entire animal was recognized, and each was thought to represent a phyllocarid crustacean in its own right. Now that the whole animal can be examined in fossil form (Collins, 1996), it is clear that two very large eyes were one of its striking features, each providing information to a central coordinating nervous system.

Eyes that are even more remarkable can be seen in fossils of 
another Burgess Shale organism of uncertain affinity, known as Opabinia. According to the reconstruction and interpretation provided by Briggs et al. (1994). Opabinia had five large eyes at the front of the head and a long flexible proboscis that ended in an array of grasping spines used to capture prey as the animal swam rapidly over the seafloor relying on its lateral lobes for propulsion and using its tail as a stabilizer.

Throughout 500 million years of animal evolution, every advance that a predator could make to its effectiveness as a hunter had to be countered by comparable improvements in the survival ability of its prey, if one or the other were to avoid extinction. In this way, sense organs and coordinating neural systems were under constant selective pressure to promote their improvement. Cranial expansion by hominids faced with completely new and unprecedented predatory challenges appears to have been one of the solutions.

\section{A Glimpse of How Early Humans Started to Overcome the Threat of Predation}

There can surely be no doubt that humans eventually established their current dominance in the natural world through intelligence and its product, technology. But were the initial steps along this path also mediated in this way? I have the impression that some of the evidence from the Swartkrans cave confirms this possibility.

Excavation revealed that the Member 3 deposit accumulated in a roofed erosional gully, about $20 \mathrm{~m}$ long and up to $5 \mathrm{~m}$ wide, running between the west wall of the cave and a vertical bank of older sediments on the east side of the gully. Initially I was not aware that the calcified sediment in this gulley was different from that further to the east, but when pieces of burnt bone started turning up with regularity, suspicions were aroused and a near-vertical unconformable contact became apparent between the contents of this gully and what surrounded it. The excavation proceeded to a depth of 850 cms and produced 59,488 pieces of fossil bone, including 9 fossils of robust australopithecines, and 270 pieces of bone that showed signs of having been burnt. Careful chemical and histological examinations confirmed that the bones had been exposed to fire and 
it was possible to estimate the approximate temperatures to which each had been subjected (Brain and Sillen, 1988; Sillen and Hoering, 1993; Brain, 1993b).

It is to be expected that natural grass fires passing the entrance of a cave should burn any pieces of bone lying around, and that these could later make their way back into the lower parts of the cave. In fact, three pieces of fossilized burnt bone had turned up in the Lower Bank of Member 1 and one may assume that the burning could have occurred in this way. But when pieces of burnt bone made their appearance in 17 excavation grid squares $(1 \mathrm{~m} \times 1 \mathrm{~m})$ and in up to 23 vertical excavation spits (each $10 \mathrm{~cm}$ thick) in the newly exposed Member 3 deposit, one is obviously dealing with a different situation. The interpretation that we proposed was that fires had been tended in the entrance area of the Member 3 gully repeatedly during the accumulation period of this sedimentary profile, and that pieces of bone heated in these fires had made their way down the talus slope to their final repository. There is no evidence that people at this time had mastered the technique of fire making, but had presumably collected burning branches from natural, lightning-induced grass fires - which are very much a feature of the highveld grassland in early summer - and brought this fire back to their sleeping place. If Member 3 is about one million years old, hundreds of thousands of years would probably have had to pass before the deliberate making of fire became a reality. But whatever the source of the fire, its presence at the cave entrance would have given these early human groups some measure of protection from the ever-present danger of waiting leopards.

In addition to the burnt bones, Member 3 also provided 14 bone pieces with unmistakable cut marks on them and 2 with chop marks. Such damage has not been seen on any of the fossils from Members 1 and 2, suggesting that hominid meat-eating at the cave, presumably round a campfire, became a reality then. Presumably, without the protection afforded by fire, it would have been too dangerous to bring meat to the cave for fear of attracting other carnivores. In my view, fire-management of this kind must have represented a critical early step in human emancipation from subservience to more powerful carnivores, which ultimately led to their domination. 
As a result of further intelligence-driven technology, humans then went on to become highly effective social hunters or predators in their own right. The selective pressures driving this process were presumably similar to those that had allowed the human emergence from a former subservient role.

Among the variety of selective pressures that drove the evolution of the large human brain, it can be argued that the demands of predation-first in surviving its dangers and later in the successful practice-were ever present and powerful in their effects.

\section{Some Constraints on a Technologically Competent Animal}

By any standards, the human animal is a very successful one. Homo sapiens is the most dominant species that the world has seen thus far, even if it is also the most destructively invasive one. This dominance is the result of its intelligence, most often translated into tangible technology, so it is perhaps worthwhile to enquire why no other animals have not followed the same route of brain expansion that has characterised the human lineage. It seems to me that there are at least five obvious constraints that would apply to any candidate for the role of a "technologically-competent animal." Although some would apply only if the candidate were a mammal, they are:

1. A critical minimum brain size. As was pointed out by Phillip Tobias (1971) in a previous James Arthur Lecture, the human brain is characterized by a very large number of "extra neurons," over and above those needed to handle the basic functions of the body. These are the equivalent of the computer hardware needed to process incoming information and convert it into intelligent responses. For human-style intelligence, it seems that a volume of at least $500 \mathrm{cc}$ of "extra" neural tissue hardware is required, so a constraint is inevitably imposed on the minimum size of an animal that could afford and accommodate such additional brain tissue.

2. Appropriate birth-canal adjustments to allow the passage of the offspring's large head in such technologically-competent mammals. 
3. Suitable appendages for manipulating objects related to the technology in question.

4. A social organization that would promote the collaborative effort required for the successful fulfillment of any major technological undertaking.

5. A languagelike communication system that would allow the exchange of concepts between individuals.

By way of speculation, I would like to conclude with the consideration of several contemporary organisms that might, in some respects at least, qualify as future candidates for evolution to convert into technologically competent animals.

Let us start with an invertebrate, or any molluscan cephalopodan octopus, cuttlefish or squid. All have 8 or 10 highly mobile appendages, each equipped with numerous suction cups; anyone who has watched an octopus build its shelter in a rock pool from stones that it has selected, carried, and positioned with care and precision will have no doubt as to the manipulatory skill of these animals. The sense organs of a cephalopod-including the beautiful eyes of cuttlefish with their W-shaped irises, which allow vision forward and backward at the same time-feed into central nervous systems that are very different from those of mammals. Though different, their series of ganglia and legendary giant axons are highly effective and allow these animals to communicate in various manners, such as through intricate patterns and colours of their skins (Holloway, 2000). Some of the giant squids are already very large and it is quite conceivable that the neural hardware needed for a fully technologically-competent squid could be accommodated in one of these animals if selective pressures developed to drive the process. It would be fun to see such creatures "conquering the land" in their waterfilled "squidmobiles."

In this context, birds should surely not be ignored, as a number of species have higher brain-to-body weight ratios than is the case in humans. Consider the case of the African Grey Parrot, so thoroughly studied by Irene Pepperberg (1999), with its remarkable repertoire of vocalizations. When I was a child, my family had a number of African parrots as pets and I was much impressed with the 
dexterity they showed in manipulating objects with their feet. For technological competence, such birds would obviously have to be very much larger, and the interesting image of a parrot with human brain proportions is certainly an interesting and perhaps achievable one, given appropriate selective pressures.

Among mammal candidates, dolphins and whales immediately come to mind. Dolphins particularly deserve attention, for they are very encephalized. social and make use of an intricate communication system. Body size is not a problem and their rudimentary pelves would easily allow the birth of large-headed offspring. What I see as a serious disadvantage is that they have no manipulative appendages; the forelimbs having become so highly specialised as flippers that they may be beyond evolutionary recall. But just how evolution can "tinker" with an already specialized forelimb is exemplified by the well-documented case of the giant panda's "pseudo-thumb" (Gould, 1978; Endo et al., 1999), which came about after a dietary change from a bear-like omnivorous carnivore to a specialised feeder on bamboo. The necessity to manipulate bamboo shoots with hands already specialised for walking saw the modification of both the radial sesamoid and accessory bone to form "a double pincer-like apparatus in the medial and lateral sides of the hand, respectively, enabling the panda to manipulate objects with great dexterity" (Endo et al., 1999). Among carnivores, this kind of object manipulation is not an isolated case: Californian sea-otters have long been known to pick up whole stones and rest them on their bellies, which are then used as anvils against which they break open mollusk shells. Given considerable increase in brain and body size, a variety of carnivores could conceivably become technologically competent in the human sense. I sometimes regret the fact that we humans had not, in fact, emerged from a good carnivore, rather than primate stock. I suspect that, as a species, our natures might have been less devious.

\section{A Final Comment from Raymond Dart}

In this lecture, I have told a story, as I see it, of predation's role in the evolution of sense organs and intelligence throughout the span 
of animal life, culminating in a specific case of human brain expansion. I suspect that, had it not been for the appearance of effective predators during the Cambrian explosion of animal life, we would still be luxuriating in the tranquil seas of the Garden of Ediacara. Furthermore, had it not been for abundant predators in the new habitats forced on early hominids by the effects of global cooling, we would still be in a Miocene-style forest, enjoying the abundant fruits of the forest.

Shortly before he died, Raymond Dart said to me, "Never let the facts get in the way of a good story." It remains to be seen how many disruptive facts will intrude on this particular story in the years to come.

\section{Acknowledgments}

I would like to thank Ian Tattersall for his invitation to me to give this James Arthur Lecture and Jeff Laitman for his kind recommendation in this regard. Ken Mowbray has been very helpful with arrangements for my visit to New York-a visit that also allowed me to spend some time in the Bahamas en route, examining specific issues of carbonate sedimentation on the island that are of particular relevance to my current Namibian fossil project. I am most grateful to have had this opportunity.

\section{REFERENCES}

Aiello. L. C.. and P. Wheeler

1995. The expensive tissue hypothesis. The brain and the digestive system in human and primate evolution. Curr. Anthropol. 36(2): 199-221.

Ardrey, R.

1961. African genesis. A personal investigation into the animal origins and nature of man. London: Collins.

Bengtson, S., and Y. Zhao

1992. Predatorial borings in Late Precambrian mineralised exoskeletons. Science 257: $367-369$.

Berger, L. R., and R. J. Clarke

1995. Eagle involvement in the accumulation of the Taung child fauna. J. Hum. Evol. 29: 275-299. 
Brain. C. K.

1969. The contribution of Namib Desert Hottentots to the understanding of australopithecine bone accumulations. Sci. Pap. Namib Res. Stat. 39: 13-22.

1981a. The hunters or the hunted? An introduction to African cave taphonomy. Chicago and London: Univ. Chicago Press.

1981b. The evolution of man in Africa: was it a consequence of Cenozoic cooling? Alex. L. Du Toit Memorial Lecture No. 17. The Geological Society of South Africa. Annexure to Vol. 84: 1-19.

1984. The terminal Miocene event: a critical environmental and evolutionary episode? In J. C. Vogel (ed.), Late Cenozoic palaeoclimates of the southern hemisphere, pp. 491-498. Rotterdam and Boston: A. A. Balkema.

1993a. Swartkrans. A cave's chronicle of early man. Pretoria: Transvaal Museum Monograph No. 8.

1993b. The occurrence of burnt bones at Swartkrans and their implications for the control of fire by early hominids. In C. K. Brain (ed.), Swartkrans. A cave's chronicle of early man, pp. 229-242. Pretoria: Transvaal Museum Monograph No. 8.

1997a. The contribution of Raymond Dart to the development of cave taphonomy. Palaeontologia Africana 33: 81-83.

1997b. The importance of Nama Group sediments and fossils to the debate about human origins. Palaeontologia Africana 34: 1-13.

Brain, C. K., and P. Shipman

1993. The Swartkrans bone tools. In C. K. Brain (ed.), Swartkrans. A cave's chronicle of early man, pp. 195-215. Pretoria: Transvaal Museum Monograph No. 8.

Brain, C. K., and A. Sillen

1988. Evidence from the Swartkrans cave for the earliest use of fire. Nature 336(6198): 464-466.

Brain, C. K., and Watson, V.

1992. A guide to the Swartkrans early hominid cave site. Ann. Transvaal Mus. $35(25): 343-365$.

Briggs, D. E. G., D. H. Erwin, and F. J. Collier

1994. The fossils of the Burgess Shale. Washington and London: Smithsonian Institution Press.

Brightman, M. and P. Westrop

1999. Crowned Eagle attack on an African child. Honeyguide 45(2): 133-134.

Broom, R., and J. T. Robinson

1949. A new type of fossil man. Nature 164: 322.

Buss, L. W., and A. Seilacher

1994. The Phylum Vendobionta: a sister group of the Eumetazoa. Paleobiology 20(1): $1-4$.

Cande, S. C., J. M. Stock, R. D. Müller, and T. Ishihara

2000. Cenozoic motion between East and West Antarctica. Nature 404: 145-150.

Clark, P. U., R. B. Alley and D. Pollard.

1999. Northern hemisphere ice-sheet influences on global climate change. Science 286: 1104-1111. 
Collins, D.

1996. The "evolution" of Anomalocaris and its classification in the Arthropod Class Dinocarida (Nov.) And Order Radiodonta (Nov.). J. Paleontol. 70(2): 280-293.

Conway Morris, S.

1993. The fossil record and the early evolution of the Metazoa. Nature 361: 219225.

Dart, R. A.

1925a. Australopithecus africanus: the man-ape of South Africa. Nature 115(2884): 195-199.

1925b. A note on Makapansgat: a site of early human occupation. S. Afr. J. Sci. 26: $454-455$.

1953. The predatory transition from ape to man. Intern.l Anthropol. Linguistic Rev. 1: 201-218.

1956. Cultural status of the South African man-apes. Smithsonian Report No. 4240: $317-338$.

1957a. The Makapansgat australopithecine osteodontokeratic culture. Proceedings of the third Pan-African Congress on Prehistory (Livingstone, 1955). London: Chatus and Windus.

1957b. The osteodontokeratic culture of Australopithecus prometheus. Pretoria: Transvaal Museum Memoir No. 10.

Denton, G. H.

1995. The problem of Pliocene paleoclimate and ice-sheet evolution in Antarctica. In E. S. Vrba et al. (ed.) Paleoclimate and evolution with emphasis on human origins, pp. 213-229. New Haven and London: Yale University Press.

Emiliani. C.

1955. Pleistocene temperatures. J. Geol, 63: 538-578.

Endo, H., D. Yamagiwa, Y. Hayashi, H. Koie, Y. Yoshiki and J. Kimura

1999. Role of the giant panda's pseudo thumb. Nature 397: 309-310.

Fedonkin, M. A., and B. M. Waggoner

1997. The Late Precambrian fossil Kimberella is a mollusc-like bilateral organism. Nature $388: 868-871$.

Germs. G. J. B.

1972. New shelly fossils from the Nama Group, South West Africa. Am. J. Sci. 272: $752-761$.

Gould. S. J.

1978. The panda's peculiar thumb. Natural History 87(9): 20-30.

Grant. S. W. F.

1990. Shell structure and distribution of Cloudina, a potential index fossil for the Terminal Proterozoic. Am. J. Sci. 290: 261-294.

Gürich. G.

1933. Die Kuibis-Fossiliender Nama Formation von Südwest Afrika. Palaeontol. Z. $15: 137-154$.

Hendey, Q. B.

1974. The Late Cenozoic Carnivora of the south-western Cape Province. Ann. S. Afr. Mus. 63: 1-369. 
Hoffman, P. F., A. L. Kaufman, G. P. Halverson, and D. P. Schrag

1998. A Neoproterozoic snowball earth. Science 281: 1342-1346.

Hoffmann. K.-H.. and A. R. Prave

1996. A preliminary note on a revised subdivision and regional correlation of the

Otavi Group based on glaciogenic diamictites and associated cap dolostones. Commun. Geol. Surv. Namibia 11: 77-82.

Hsu, K. J., L. Montadert, D. Bernoulli, M. B. Cita, A. Erickson, R. E. Garrison, R.

B. Kidd, F. Melieres, C. Muller, and R. Wright

1977. History of the Mediterranean salinity crisis. Nature 267: 399-403.

Holloway, M.

2000. Cuttlefish say it with skin. Natural History 4/00: 70-76.

Kirschvink, J. L.

1992. Late Proterozoic low-latitude glaciation: the Snowball Earth. In J. W.

Schopf, and C. Klein (eds.): The Proterozoic biosphere. A multidisciplinary study, pp. 51-52. Cambridge: Cambridge Univ. Press.

Lear, C. H., H. Elderfield, and P. A. Wilson

2000. Cenozoic deep-sea temperatures and global ice volumes from $\mathrm{Mg} / \mathrm{Ca}$ in benthic foraminiferal calcite. Science 287: 269-272.

Martinez-Navarro, B., and P. Palmquist

1996. Presence of the African saber-toothed felid Megantereon whitei (Broom, 1937) (Mammalia, Carnivora, Machairodontinae) in Apollonia-1 (Mygdonia Basin, Macedonia, Greece). J. Arch. Sci. 23: 869-872.

McMenamin, M.

1986. The garden of Ediacara. PALAIOS 1: 178-182.

Narbonne, G. M.

1998. The Ediacaran biota: a Terminal Neoproterozoic experiment in the evolution of life. GSA Today 8(2): 1-6.

Narbonne, G. M., B. Z. Saylor and J. P. Grotzinger

1997. The youngest Ediacaran fossils from southern Africa. J. Palaeontol. 71(6): 953-967.

Newman. R. A.

1993. The incidence of damage marks on Swartkrans fossil bones from the 19791986 excavations. In C. K. Brain (ed.), Swartkrans. A cave's chronicle of early man, pp. 217-228. Pretoria: Transvaal Museum Monograph No. 8.

Nilsson, G. E.

2000. The cost of a brain. Natural History 108(10): 66-73.

Oakley, K.

1956. The earliest fire-makers. Antiquity 30: 102-107.

Partridge, T. C., B. A. Wood, and P. B. De Menocal

1995. The influence of global climatic change and regional uplift on large-mammalian evolution in East and southern Africa. In: Vrba et al. (Eds.) Paleoclimate and evolution, with emphasis on human origins, pp. 331-355. New Haven and London: Yale University Press.

Pepperberg, I. M.

1999. The Alex studies. Cognitive and communicative abilities of grey parrots. Cambridge, MA.: Harvard University Press. 
Robinson, J. T.

1961. The australopithecines and their bearing on the origin of man and of stone tool-making. S. Afr. J. Sci. 57: 3-13.

Ryan, W. B. F.

1973. Geodynamic implications of the Messinian crisis of salinity. In C. W. Drooger, (ed.), pp. 26-38, Messinian events in the Mediterranean. Amsterdam: North Holland.

Seilacher, A.

1992. Vendobionta and Psammocorallia: lost constructions of Precambrian evolution. J. Geol. Soc. London 149: 609-613.

1999. Biomat-related lifestyles in the Precambrian. PALAIOS 14: 86-93.

Sillen, A., and T. Hoering

1993. Chemical characterisation of burnt bones from Swartkrans. In C. K. Brain (ed.): Swartkrans. A cave's chronicle of early man, pp. 243-250. Pretoria: Transvaal Museum Monograph No 8.

TattersalI, I.

2000. Once we were not alone. Sci. Am. 282(1): 56-62.

Tobias, P. V.

1971. The brain in hominid evolution. New York and London: Columbia Univ. Press

Vrba, E. S.

1995. The fossil record of African antelopes (Mammalia, Bovidae) in relation to human evolution and evolution. In E. S. Vrba (ed.), Paleoclimate and evolution, with emphasis on human origins, pp. 385-424. New Haven and London: Yale Univ. Press.

Watson. V.

1993. Composition of the Swartkrans bone accumulations in terms of skeletal parts and animals represented. In C. K. Brain (ed.), Swartkrans. A cave's chronicle of early man, pp. 35-74. Pretoria: Transvaal Museum Monograph No. 8 .

Whiteaves, J. F.

1892. Description of a new genus and species of phyllocarid crustaces from the Middle Cambrian of Mount Stephen, B.C. Can. Rec. Sci. 5: 205-208. 

James Arthur lecture on the evolution of the human brain. American Museum of Natural History

Received on: 03-23-05

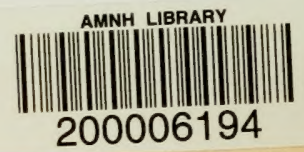

